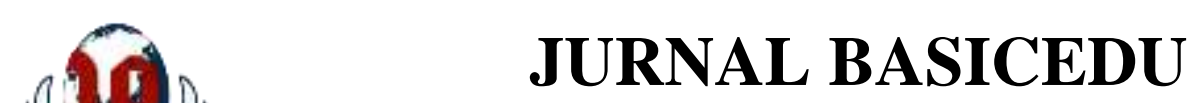

Volume 5 Nomor 5 Tahun 2021 Halaman 3689 - 3696

Research \& Learning in Elementary Education https://jbasic.org/index.php/basicedu

\title{
Pengaruh Model Contextual Teaching Learning (CTL) Berbantuan Google Meeting terhadap Kemampuan Pemecahan Masalah di Sekolah Dasar
}

\author{
Citra Ayu Sholihah ${ }^{1 凶}$, Sri Lestari Handayani ${ }^{2}$ \\ Pendidikan Guru Sekolah Dasar, Universitas Muhammadiyah Prof.Dr.Hamka, Indonesia ${ }^{1,2}$ \\ E-mail: citraayusholihah@gmail.com ${ }^{1}$, srilestarih@uhamka.ac.id $^{2}$
}

\begin{abstract}
Abstrak
Kajian dengan maksud melihat yang memengaruhi model CTL (Contextual Teaching Learning) untuk meningkatkan yang terampil dari penyelesaian permasalahan pada mata pelajaran IPA siswa kelas III SDN Pekayon 09 Pagi keberagaman kajian dengan yang dipergunakan Kuantitatif Eksperimen, mengumpulkan pendataan dan juga populasi kajian ini adalah keseluruhan dari peserta didik pada Kelas III dengan dua pembagian A dan B. Kemudian diambil garis besarnya jika CTL mempunyai hal yang memengaruhi dengan penyelesaian permasalahan yang ada. Instrument terlebih dahulu diuji cobakan kepada 34 siswa kelas IIIA di SDN Pekayon 09 Pagi dari uji validitas skor hasil belajar IPA siswa dengan rumus product moment didapat 20 butir soal yang valid dan reliable. kemudian dengan kepenujukan meningkatkan pembuktian uji test melihat penilaian dua besarannya hingga $0,000<0,05$. Bahwa diketahui hasilnya terdapat pengaruh pemecahan masalah.
\end{abstract}

Kata Kunci: CTL (Contextual Teaching Learning), IPA, Pemecahan Masalah.

Abstract

A study with the aim of looking at what influences the CTL (Contextual Teaching Learning) model to improve skills in solving problems in science subjects for third grade students at SDN Pekayon 09 Pagi. students in Class III with two divisions A and B. Then the outline is taken if CTL has things that affect the resolution of existing problems. The instrument was first tested on 34 grade IIIA students at SDN Pekayon 09 Pagi. From the validity test of students' science learning outcomes with the product moment formula, 20 valid and reliable questions were obtained. then with the appointment of increasing the proof of the test test, see the assessment of the two magnitudes up to $0.000<0.05$. It is known that the results have the effect of problem solving.

Keywords: CTL (Contextual Teaching Learning), Science, Problem Solving.

Copyright (c) 2021 Citra Ayu Sholihah, Sri Lestari Handayani

Corresponding author :

Email : citraayusholihah@gmail.com

DOI : https://doi.org/10.31004/basicedu.v5i5.1231 ISSN 2580-1147 (Media Online) 
3690 Pengaruh Model Contextual Teaching Learning (CTL) Berbantuan Google Meeting terhadap Kemampuan Pemecahan Masalah di Sekolah Dasar - Citra Ayu Sholihah, Sri Lestari Handayani DOI: https://doi.org/10.31004/basicedu.v5i5.1231

\section{PENDAHULUAN}

Belajar adalah proses aktif, anak-anak belajar dengan mengkonstruksi apa yang telah mereka pelajari berdasarkan apa yang mereka ketahui, daripada menerima sesuatu secara pasif. Pemahaman ini berakar pada sudut pandang konstruktivisme. Konstruktivisme itu sendiri sering muncul di berbagai bidang, termasuk psikologi, filsafat, sosiologi, dan pendidikan, dan sangat penting untuk pembelajaran ilmiah. Diperuntukan dari saintifik dengan kemampuan mendorong pelajar untuk bangun dari wawasan, melatih mereka dengan memikirkan ataupun menyelesaikan permasalahan dengan yang berdampak pada permasalahan yang sebenarnya.

Siswa yang tertarik pada sains akan merasa belajar sains itu menyenangkan, sehingga mereka akan antusias tentang bagaimana mata kuliah sains berhubungan dengan pengalaman mereka sehari-hari. Pembelajaran IPA sekedar hafalan fan yang terkonsep jawaban pertanyaan juga berharap dengan pemahaman, pengamatan dan analisa, memecahkan permasalahan pembelajaran di masa depan dan kehidupan sehari-hari.

Pembelajaran IPA memiliki peran yang krusial proses pendidikan serta perkembangan sains berusaha merangsang yang menjadi acuan, daya mampu perkembangan dan paham kedepan sehingga teman-temannya untuk berkembang. Selain materi dan soal, model pembelajaran CTL juga digunakan untuk mempraktekkan pembelajaran saintifik di keseharian akan segera memahami proses berpikir sebelum mereka memahami masalah dan memberikan solusi.

Menurut (Jatisunda, 2017) berpendapat jika memupuk daya mampu memecahkan permasalahan saja tidak cukup, tetapi juga perlu menumbuhkan keyakinan, penyelesaian kita cukup dengan berhadapa dengan apa yang dimaksud untuk menyelesaikan permasalahan ini: 1) Langkah ini meliputi memahami/mengintensifkan kondisi masalah, memilih fakta berdasarkan data yang tersedia, menentukan hubungan antar fakta, dan menentukan masalah. Misalnya, penentuan apa yang dicari ataupun metode masalah. 2)Perencanaan menyelesaikan pada langkah ini melibatkan mengidentifikasian yang menjadi fokusnya. Kurangnya pemecahan masalah disekolah terutama kepada siswa yang tidak diberikannya latihan secara langsung sehingga siswa tidak mengetahui cara menyelesaikannya dengan benar. Diperuntukan perolehan daya mampu dengan menyelesaikan masalahnya, mempunyai apa yang dirasakan dengan permasalahan dan hasil kajian memperlihatkan penyelesaian yang ada.

Kemampuan pemecahan masalah dipandang sebagai bagian fundamental dari pembelajaran IPA Gok \& Silay (2010:15). Pemecahan masalah ialah yang menjadi fase penerapan daya mampu, perolehan keadaan baru dan dukungan Husna (2012:24). Diperlihatkan dengan apa yahng mendekatinya, dengan orientasi yang dimaksud ataupun orientasi kepada pendidiknya.

Model Pembelajaran CTL itu menuntut jika pembelajaran tidak dari perhatian saja akan tetapi dari fase yang langsung dari apa yang dialaminya. (Susiloningsih, 2016, p. 58) Pendekatan CTL yang berpusat pada mahasiswa mampu menanamkan kebiasaan pemecahan masalah, berpikir kritis, kreatif, dan mandiri. Menggali potensi mahasiswa berdasarkan pengalaman yang telah dimiliki untuk dihubungkan dengan pengetahuan yang akan dipelajari.

Menurut Blanchard Trianto (2009:104) mengatakan pembelajaran CTL adalah menjadi terkonsep dan bantuan peserta didik dengan keadaan sebenarnya, dukungan dan wawasan. Kemudian konstruksi ini dengan penekanan yang ada, hafalan ataupun dari apa yang dialaminya, acuannya dengan yang menjadi anggapannya ataupun yang terkonsep dari hubungan materi ataupun yang dipergunakan dari apa yang pernah dirasakannya secara personal.

Model pembelajaran CTL mempunyai sintaks dengan enam tahapan. Menurut Julianto, dkk (2011:77) sintaks model pembelajaran CTL yaitu: “(1) Melaksanakan kegiatan inkuiri untuk semua topik; (2) Mengembangkan sikap ingin tahu; (3) Menciptakan masyarakat belajar; (4) Menghadirkan model; (5) 
Melakukan refleksi; (6) Melakukan penilaian yang sebenarnya. Dalam proses pembelajaran terdapat tujuan pembelajaran yang diharapkan dapat dicapai setiap siswa setelah mengikuti pembelajaran".

Salah satu materi pokok yang diajarkan di SDN Pekayon 09 Pagi kelas V semester ganjil dengan mengacu pada kurikulum. Adapun standar kompetemsi (SK) yang diharapkan adalah memahami sifat-sifat benda padat, cair, gas dan bagian-bagiannya sedangkan Kompetensi Dasar adalah a. Mengidentifikasi sifatsifat benda padat, cair, gas dan bagian- bagiannya b. Perubahan wujud benda yang dapat dibalik dan tidak dapat dibalik tetapi penelitian ini, materi dibatasi hanya pada menemukan sifat-sifat benda, wujud benda, perubahan benda. 1). Benda padat banyak terdapat disekitar kita. Benda padat mempunyai bentuk tetap. 2). Benda cair dengan yang utama sekali dengan ketidak tetapan. Bentuk perubahan dengan ikutnya yang menjadi media, air dan bentuknya mangkuk pemidahan ke botol ataupun perubahan volume yang ada. 3). Benda Gas dengan keberagaman ataupun penemapatan penyimpanan ruangnya, media dan yang dikendarai dari partikelnya dengan perubahan, penyusunannya dengan pergerakan yang ada.

Salah satu ketrampilan terkait dengan karakter ialah penyelesaian permasalahan, daya mampu menyelesaikan masalahnya dan kaitan yang terkait, perkembangan daya mampu dengan pelaksanaan dan mengambil garis besarnya beralaskan pemikiran yang sesuai dengan kenyataan, kecermatan dan yang menjadi harapan kemampuan pemecahan masalah dikeseharian, dengan kesuksesan dan korelasi yang ada, ketekunannya dan mempunyai sikap yang dihargai dan mempunyai keingintahuan yang tinggi, penyelesaian masalah dan sikap yang baik.

\section{METODE PENELITIAN}

Penelitian ini merupakan penelitian kuantitatif yaitu dalam pengolahan data berbentuk kuantitas/jumlah/angka. Penelitian ini dilakukan di SDN Pekayon 09 Pagi tahun ajaran 2020/2021 pada semester genap. Populasi dan keseluruhan subyek dan objek yang menjadi sasaran penelitian. Kedudukannya dengan yahng umum dari kajian. Mulyatiningsih (2011: 19). Adapun populasi pada kajian ialah dari kelas yang menjadi fokus jumlahnya \pm 35 siswa.

Sampel adalah bagian dari jumlah dan karakteristik yang dimiliki oleh populasi. Sampel yang digunakan dalam penelitian proposal ini adalah sampel jenuh. Sampel jenuh adalah teknik pengambilan sampel apabila semua populasi digunakan sebagai sampel. Artinya seluruh anggota sampel menjadi objek peneliti. Anggota sampel dalam penelitian ini yaitu seluruh siswa kelas IIIA dan IIIB SDN Pekayon 09 Pagi yang berjumlah 69 siswa.

Penelitian ini menggunakan metode atau desain penelitian quasi experiment. Adapun pengertian dari quasi experiment adalah suatu desain atau metode eksperimen semua yang dipandang cukup sulit dalam pelaksanaannya, ciri-ciri dari desain penelitian ini adalah adanya kelas kontrol tetapi sampel tidak diambil secara acak (Ismail, 2018). Rancangan quasi experiment dipergunakan dari kajian dengan rancangan penelitiannya, sedangkan yang membedakannya adalah kelompok atau kelas tidak dipilih secara acak pada desain the non-equivalent design.

Teknik pengambilan sampel yang dipilih adalah non- probability sampling, yang tidak memberi peluang sama pada setiap individu untuk dipilih sebagai sampel. Maka, pengambilan sampel menggunakan metode jenuh. Definisi dari sampling jenuh adalah teknik yang digunakan jika keanggotaannya dijadikan sampelnya Sugiyono (2016:81). Bedasarkan pada teknik pengambilan sampel, maka siswa kelas VA yang berjumlah \pm 35 orang akan menjadi kelas kontrol, sedangkan siswa kelas VB yang berjumlah \pm 35 orang akan menjadi kelas eksperimen.

Kajian ini dengan pengambilan berasal dari kelas IIIA dan kelas IIIB dengan jumlah keseluruhan peserta didik sebanyak \pm 69 orang. Masing-masing kedua kelas tersebut ada \pm 35 peserta didik, yang mana kelas IIIA yang merupakan kelas control dan kelas IIIB merupakan kelas eksperimen. 
3692 Pengaruh Model Contextual Teaching Learning (CTL) Berbantuan Google Meeting terhadap Kemampuan Pemecahan Masalah di Sekolah Dasar - Citra Ayu Sholihah, Sri Lestari Handayani DOI: https://doi.org/10.31004/basicedu.v5i5.1231

Menurut sugiyono Sugiyono (2016:61), variabel adalah "segala sesuatu yang berbentuk apa saja yang ditetapkan oleh peneliti untuk dipelajari sehingga diperoleh informasi tentang hal tersebut, kemudian ditarik kesimpulannya". Contohnya dari yang terikat dan bebas untuk penyelesaian masalahnya.

Variabel penelitiannya adalah model pembelajaran CTL dan pemecahan masalah IPA siswa Kelas 3, sehingga instrument yang diberikan setelah seluruh fase pembelajaran dengan pengelompokan yang ada, menerapkan yang menjadi media dan tes pilihan ganda.

Validitas ialah yang memperlihatkan yang menjadi tolak ukur, kemampuan dan media yang ada. Kemudian instrumen yang dipunyai anggapannya Arikunto (2015:160). "Uji validitas yang akan digunakan pada penelitian ini adalah rumus korelasi product moment dengan angka kasar. Uji realibilitas adalah sejauh mana hasil pengukuran dengan menggunakan objek yang sama akan menghasilkan data yang sama Sugiyono (2013:177). Uji realibilitas pada penelitian ini menggunkan rumus K-R. 20”

Uji normalitas ialah sebuah pengujian, memiliki tujuan melihat distribusi yang diteliti, dengan data kajian memakai uji Liliefors. Uji homogenitas ialah pengujian memiliki variasi dengan mengetahuinya, pelaksanaan menguji homogenitasnnya mempergunakan uji $\mathrm{F}$.

Setelah mengetahui data pendistribusian serta homogennya bertujuan untuk membuktikan dan mengetahui adanya pengaruh yang signifikan ketika sebelum dan sesudah diberikan perlakuan penerapan metodenya IPA siswa kelas 5 SDN PEKAYON 09 PAGI. Uji sample t test dengan mempergunakan pembanding yang tidak memiliki korelasi.Singgih Santosa (2014:79)

\section{HASIL DAN PEMBAHASAN}

Kajian pelaksanaan dengan tiga tahapan dengan dengan memberi pretes, awalannya dengan apa yang dipelajari menjadi tolak ukur, daya mampu pemberlakuannya. Kemudian akan menjadi kontrol memakai model dengan keberlangsungan perlakuannya dan penerapan dari Contextual Teaching Learning. Pasca pemberlakuan dengan pemberian tes itu, dengan apa yahng berkembang dan penyelesaiannya:

Tabel 1. Nilai rata-rata Pretest dan Posttest Kontrol dan kelas Eksperimen

\begin{tabular}{|l|l|c|c|}
\hline & Kelas & $n$ & rata-rata \\
\hline \multirow{2}{*}{ Pretest } & Eksperimen & 35 & 89,47 \\
\cline { 2 - 4 } & Kontrol & 35 & 73,68 \\
\hline \multirow{2}{*}{ Posttest } & Eksperimen & 35 & 88,23 \\
\cline { 2 - 4 } & Kontrol & 35 & 76,19 \\
\hline
\end{tabular}

Diperhatikan nilainya dari tabel 1. Kemampuan penyelesaian permasalahan dengan kontrolnya 76,19 serta rata ratanya dengan angka 88,23, penilaiannya dengan pengujian hingga 73,68 dan nilai rata-rata posttest sebanyak 89,47 . Ketika diperhatikan pembandingnya dengan beberapa hal dan penyelesaian masalahnya. Perolehan data kajian berikutnya pelaksanaan yang normal dan juga pendistribusiannya, kelas kontrol dengan jumlah siswa 35 .

Tabel 2 Uji Normalitas Kelas Eksperimen dan Kelas Kontrol

\begin{tabular}{|l|l|c|c|c|c|}
\hline & Kelas & $n$ & $L_{\text {hitung }}$ & $L_{\text {tabal }}$ & Keterangan \\
\hline \multirow{2}{*}{ Pretest } & Eksperimen & 34 & 0,113 & 0,149 & \multirow{3}{*}{ Berdistribusi } \\
\cline { 2 - 6 } & Kontrol & 35 & 0,115 & 0,162 & \multirow{2}{*}{ Normal } \\
\cline { 1 - 5 } Posttest & Eksperimen & 34 & 0,021 & 0,149 & \\
\cline { 2 - 5 } & Kontrol & 35 & 0,005 & 0,162 & \\
\hline
\end{tabular}


3693 Pengaruh Model Contextual Teaching Learning (CTL) Berbantuan Google Meeting terhadap Kemampuan Pemecahan Masalah di Sekolah Dasar - Citra Ayu Sholihah, Sri Lestari Handayani DOI: https://doi.org/10.31004/basicedu.v5i5.1231

Berdasarkan uji normalitas pada tabel 2 dapat dilihat melalui Lhitung dan Ltabel dapat dilihat dari pretest kelas yang diujikan, yang mengontrol dengan Lhitung dan adapun postest dengan kepenunjukan data dari keduanya.

Uji Homogenitas pelaksanaannya mempergunakan pendataan dengan maksud melihat yang dipergunakan ataupun tidaknya.

Tabel 3 Uji Homogenitas Kelas Eksperimen dan Kelas Kontrol

\begin{tabular}{lll}
\hline Pembeda & Kelas Eksperimen & Kelas Kontrol \\
\hline Jumlah siswa & 34 & 35 \\
Nilai rata-rata & 80,67 & 80,2 \\
Varians & 14,58 & 9,69 \\
f hitung & 1,75 & 1,92 \\
f tabel & 1,73 & 1,74 \\
\hline
\end{tabular}

Daya mampu penyelesaian masalahnya dengan yang mengontrol diketahui hasil rata-rata dari homogenitas pretest 80,67 sedangkan hasil rata-rata dari homogenitas posttest 80,2 adapun $\mathrm{f}$ hitung kelas eksperimen 1,75 f hitung kelas kontrol 1,92 dengan apa yang menjadi garis besar dan homogennya.

Uji t-test pelaksanaanya itu perhatian yang memengaruhi penerapan model Contextual Teaching Learning terhadap pemecahan permasalahannya. Dapat diketahui hasil dari uji t hitung posttest eksperimen dan posttest kontrol 2,263 sedangkan hasil $\mathrm{t}$ tabel dari posttest eksperimen dan posttest kontrol 2,000 terdapat perbedaan dari data tersebut mengetahui adanya pengaruh signifikan ketika sebelumnya dengan modelnya CTL terhadap pemecahan masalah.

Tabel 4 Hasil analisis uji t-test

\begin{tabular}{|l|c|c|}
\hline & Post Eks & Post Kontrol \\
\hline Rata-rata & 86,17 & 84,56 \\
\hline Simp Baku & 4,04 & 3,81 \\
\hline Varians & 14,546 & 16,339 \\
\hline t hitung & \multicolumn{2}{|c|}{2,263} \\
\hline t tabel & \multicolumn{2}{|c|}{2,000} \\
\hline
\end{tabular}

Uji hipotesis yang bertujuan untuk membuktikan adanya pengaruh yang signifikan ketika sebelumnya ataupun dari penerapan CTL terhadap pemecahan masalah. Dapat diketahui bahwa nilai $t_{\text {hitun } q}>t_{\text {tabel }}$ $(2,263>2,000)$. Maka kedua kelompok ini terdapat signifikansinya, dengan penyelesaian masalah dan perolehan dari Contextual Teaching Learning.

Kajian ini dilaksanakan dengan maksud mengetahui hal yang memengaruhi ataupun penyelesaian masalah berupa penerapan modelnya, dilihat selain itu berdasarkan pendataan menunjukan penilaian dan penyelesaian permasalahan kelas kontrolnya.

Terdapat perbedaan hasil pemecahan masalah yang signifikan ini disebabkan karena perbedaan tahapan-tahapan pembelajaran dan proses penyampaian materi. Pada pemberlakuan penerapannya itu dengan metode konvensionalnya, pembelajaran yang utamanya dari apa yang diketahui, apa yahng dialami yang baik dengan mempergunakan pembelajaran yang ada Sumiati dan Asra (2007:14).

Dalam proses pelaksanaan pembelajaran guru berperan sebagai pemimpin untuk merencanakan pembelajaran yang berorientasi kepada tujuan pembelajaran. Guru mengatur jalannya proses pembelajaran baik secara individu maupun kelompok dan mengetahui pencapaian peserta didik dalam pemecahan masalah ebagai monitoring. Guru sebagai fasilitator akan mengatasi kekurangan yang ada pada peserta didik atau 
3694 Pengaruh Model Contextual Teaching Learning (CTL) Berbantuan Google Meeting terhadap Kemampuan Pemecahan Masalah di Sekolah Dasar - Citra Ayu Sholihah, Sri Lestari Handayani DOI: https://doi.org/10.31004/basicedu.v5i5.1231

mengembangkan kemampuan pemecahan masalah. Kegiatan yang dilakukan dengan membangkitkan konflik kognitif pada peserta didik, seperti melalui pertanyaan, memberikan analogi atau kegiatan lainnya yang dapat menimbulkan siswa untuk melakukan pemecahan masalah.

Berdasarkan pengamatan pada kelas yang penerapan yang menjadi modelnya, dengan perolehan rangsangan dan yang diketahui dikeseharian dengan model CTL, dan siswa mencari bagaimana cara masalah ini dapat terpecahkan yang secara individu dan siswa dapat memberikan kesimpulan dari masalah yang diberikan. Masalah ini berupa praktikkum yang dilakukan dirumah dengan memaparkan hasil dari praktikkum tersebut kepada peneliti sebagai bukti siswa dapat mempraktekkan dan menyimpulkan pembelajaran.

Perbedaan yang dapat dilihat dari pembelajaran kelas yang diberi perlakuan penerapan model CTL dengan kelas yang diberi perlakuan penerapan metode konvensional yaitu suasana kelas cenderung pasif karena guru tidak memberikan perlakuan. Pelaksanaanya guru lebih mendominasi daripada siswa dalam pembelajaran berpusat pada guru. Penyampaian materi juga lebih banyak satu arah yaitu, guru ke siswa sehingga tidak melibatkan siswa untuk berperan aktif dalam proses pembelajaran. Penyampaian materi biasa dilakukan melalui ceramah, tanya jawab, penugasan memberikan soal instrumen. Pembelajaran ini membuat siswa bosan, siswa cenderung menunggu informasi dari guru, dan hanya menghafal konsep saja.

Dari hasil analisis Dari hasil analisis diatas dapat dibuktikan bahwa modelnya dengan yang memengaruhi baik serta signifikan dengan daya mampu penyelesaian permasalahan. Dalam pelaksanaanya sudah optimal mencapai kemampuan pemecahan masalah dengan sangat baik karena siswa sudah pernah melakukannya dalam kehidupan sehari-hari sehingga siswa tidak bingung lagi untuk melakukan kegiatannya. Dari hambatan yang terjadi modelnya yang jelas dengan kemampuan pemecahan permasalahan.

Implikasi temuan dari penelitian ini adalah "penerapan model pembelajaran Contextual Teaching Learning (CTL) dapat memberikan pengaruh positif dan signifikan terhadap kemampuan pemecahan masalah. Hal ini dapat dilihat dari rata-rata kelas yang diberikan perlakuan berupa model pembelajaran Contextual Teaching Learning (CTL) mengalami peningkatan lebih besar daripada kelas yang tidak diberikan perlakuan berupa model Contextual Teaching Learning (CTL)".

Guru juga memiliki peran sebagai pemimpin, fasilitator, monitor, dan evaluator. Selain itu, menjawab dan memecahkan soal yang diberikan siswa menjadi lebih kritis terbukti dari memberikan pendapat atau pertanyaan pada saat diskusi kelas. Peserta didik berhasil menemukan materi yang diberikan sehingga dapat menemukan konsep secara mandiri sehingga peserta didik memiliki daya ingat yang kuat terutama untuk materi yang diberikan.

Dengan demikian penelitian ini pemberian yang memengaruhi baik danjelas dari daya mampu menjadi maksimal dengan model yang diharapkan Guru saat proses mengajar dan pembelajaran sehari-hari.

\section{KESIMPULAN}

Penelitian menunjukkan bahwa pemecahan masalah IPA pada peserta didik yang diajarkan mempergunakan CTL lebih nampak dibanding dengan diajarkan secara langsung. Setelah dilakukan penelitian terdapat adanya pengaruh. Hal tersebut dapat dibesakan dengan penilaiannya dengan eksperimen dengan kontrol dan melalui Lhitung dan Ltabel dapat dilihat dari pretest kelas eksperimen dan kelas kontrol Ltabel lebih besar dari Lhitung dan adapun posttest kelasnya dengan memperlihatkan pendistribusian yang baik. hasil rata-rata dari homogenitas pretest 80,67 sedangkan hasil rata-rata dari homogenitas posttest 80,2 adapun $\mathrm{f}$ hitung kelas eksperimen 1,75 f hitung kelas kontrol 1,92 kemudian bisa diambil garis besar yang menjadi pembeda penyelesaian masalah penerapan dengan menerapkan apa yang ada model Contextual Teaching Learning (CTL). 
3695 Pengaruh Model Contextual Teaching Learning (CTL) Berbantuan Google Meeting terhadap Kemampuan Pemecahan Masalah di Sekolah Dasar - Citra Ayu Sholihah, Sri Lestari Handayani DOI: https://doi.org/10.31004/basicedu.v5i5.1231

Penyelesaian masalah dengan jawaban dan apresiasi peserta didik dengan kebiasaan menyelesaikannya, kemudian butuhnya untuk menghitung waktu belajar keterlibatan peserta didik untuk penemuan yang menjadi konsepnya.

\section{UCAPAN TERIMA KASIH}

Penelitian yang besar umumnya tidak hanya melibatkan satu dua orang saja. Dari pihak pemberi dana, administrasi, teman-teman sejawat, serta orangtua yang memberikan cukup berarti kepada pelaksana kegiatan penelitian. Semuanya perlu dikemukakan dan diberi ucapan terima kasih mereka yang memberi konstribusi yang cukup signifikan sehingga penelitian ini berjalan dengan baik.

\section{DAFTAR PUSTAKA}

Aprilia A. Pedagogik Journal Of Islamic Elementary School (2018) Buku Tematik Terpadu,Nk,2013 Penulis: Taufina

Dayani D. R.Hasanudd In Mathematics Learning (2020)

Guru Pendidikan Dasar F. I Penerapan Model Pembelajaran Contextual Teaching And Learning (Ctl) Untuk Meningjatkan Hasil Belajar Siswa Mata Pelajaran Ips Kelas 1 Sd (2009)

Malik, Abdul. 2014. Keefektifan Pendekatan Ctl Terhadap Aktivitas Dan Hasil Belajar Ipa Materi Gaya Magnet Kelas V Sd Negeri Tegalsari 1 Kota Tegal

Nurlaili Jurnal Pendidikan Serambi Ilmu (2016) Oktaviani L.Tari N. Pedagogia (2018)

Pembelajaran Ipa Sd Farida, Nk, 2016 Penulis: Farida Nur Kumala, S.Si, M.Pd Penerbit Ediide Infografika

Rahmawati T. R. Jurnal Imiah Pendidikan Dan Pembelajaran (2018)

Utami F. D.Djatmika E. T.Sa ${ }^{e e}$ Dijah C. Seminar Nasional Teknologi Pembelajaran Dan Pendidikan Dasar 2017 (2017)

Trianto. 2008. Mendesain Pembelajaran Kontekstual Di Kelas. Jakarta: Cerdas Pustaka.

Sumiati \& Asra. 2007. Metode Pembelajaran. Bandung: Cv Wacana Primaagus Kistian, Febry Fahreza, \& Mulyadi. (2020). Perbedaan Model Pembelajaran Contextual Teaching And Learning (Ctl) Dan Ekspositori Terhadap Kemampuan Pemecahan Masalah Matematis Siswa Di Kelas Iv Sdn Peunaga Cut Ujong.

Jatisunda, M. G. (2017). Hubungan Self-Efficacy Siswa Smp Dengan Kemampuan Pemecahan Masalah Matematis. Jurnal Theorems (The Original Research Of Mathematics), 1(2), 24-30. Http://Www.Jurnal.Unma.Ac.Id/Index.Php/Th/Article/View/375

Susiloningsih, W. (2016). Model Pembelajaran Ctl (Contextual Teaching And Learning) Dalam Meningkatkan Hasil Belajar Mahasiswa Pgsd Pada Matakuliah Konsep Ips Dasar. Pedagogia: Jurnal Pendidikan, 5(1), 57. Https://Doi.Org/10.21070/Pedagogia.V5i1.89

Kistian, A., Fahreza, F., Mulyadi, D., Stkip, ), \& Meulaboh, B. B. (2020). Perbedaan Model Pembelajaran Contextual Teaching And Learning (Ctl) Dan Ekspositori Terhadap Kemampuan Pemecahan Masalah Matematis Siswa Di Kelas Iv Sdn Peunaga Cut Ujong. In Jurnal Tunas Bangsa (Vol. 7, Issue 1).

Sihono, T. (2004). Contextual Teaching And Learning (Ctl). Jurnal Ekonomi \& Pendidikan, 1(1), 63-64.

Mauke, M., Sadia, I. W., \& Suastra, I. W. (2013). Pengaruh Model Contextual Teaching And Learning Terhadap Pemahaman Konsep Dan Kemampuan Pemecahan Masalah Dalam Pembelajaran Ipa-Fisika Di Mts Negeri Negara. 
3696 Pengaruh Model Contextual Teaching Learning (CTL) Berbantuan Google Meeting terhadap Kemampuan Pemecahan Masalah di Sekolah Dasar - Citra Ayu Sholihah, Sri Lestari Handayani DOI: https://doi.org/10.31004/basicedu.v5i5.1231

Jatisunda, M. G. (2017). Hubungan Self-Efficacy Siswa Smp Dengan Kemampuan Pemecahan Masalah Matematis. Jurnal Theorems (The Original Research Of Mathematics), 1(2), 24-30. Http://Www.Jurnal.Unma.Ac.Id/Index.Php/Th/Article/View/375

Susiloningsih, W. (2016). Model Pembelajaran Ctl (Contextual Teaching And Learning) Dalam Meningkatkan Hasil Belajar Mahasiswa Pgsd Pada Matakuliah Konsep Ips Dasar. Pedagogia: Jurnal Pendidikan, 5(1), 57. Https://Doi.Org/10.21070/Pedagogia.V5i1.89

Jatisunda, M. G. (2017). Hubungan Self-Efficacy Siswa Smp Dengan Kemampuan Pemecahan Masalah Matematis. Jurnal Theorems (The Original Research Of Mathematics), 1(2), 24-30.

Khaeruddin Dan Sujiono, E.H. 2005. Pembelajaran Sains (Ipa) Berdasarkan Kurikulum Berbasis Kompetensi. Makassar: Penerbit Makassar.

Irianto, D. M Dan Yuliariatiningsih. (2008). Pendidikan Ipa Di Sekolah Dasar. Bandung: Upi. 